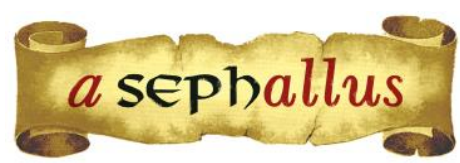

Revista aSEPHallus de Orientação Lacaniana

Núcleo Sephora de Pesquisa sobre o Moderno e o Contemporâneo

ISSN $1809-709$ X

\title{
Contradictory versions in the field of science: politicisation and misinformation in the prevention of Covid-19
}

\author{
Tania Coelho dos Santos \\ Orcid: https://orcid.org/0000-0002-5360-7864 \\ PHD from the Department of Psychoanalysis of Paris VIII (Paris, France) \\ Associate Professor, level IV in the Postgraduate Program in \\ Psychoanalytical Theory/UFRJ (Rio de Janeiro, Brazil) \\ Brazilian National Council for Scientific and Technological Development (CNPQ) level $1 \mathrm{C}$ researcher \\ President of Instituto Sephora de Ensino e Pesquisa de \\ Orientação Lacaniana/ ISEPOL (Rio de Janeiro, Brazil) \\ Psychoanalyst Member of the Ecole de La Cause Freudienne (Paris, France) \\ Psychoanalyst Member of the Brazilian School of Psychoanalysis \\ and the World Association of Psychoanalysis (Brazil) \\ Member of the University Association for Research \\ in Fundamental Psychopathology (Rio de Janeiro, Brazil)
}

E-mail: taniacs@openlink.com.br

\begin{abstract}
For $80 \%$ of those infected with Covid-19, the name of the infection that the new coronavirus causes, it is nothing more than an asymptomatic viral infection with mild or moderate symptoms. However, $5 \%$ of infected individuals develop very severe symptoms, whose treatment is quite complex and can lead them to death. It appears that in the treatment of this disease, the consolidated medical-scientific knowledge, throughout the experience in the treatment of similar respiratory infections, is of no use. Thus, an enormous inhibition was produced among the attending physicians when explaining to the press that the use of traditional methods of treatment was still valid and would not need complicated scientific experiments to justify them. In the public affected by the campaigns moved by the press we observed psychopathological effects of intense anguish, insomnia, shortness of breath, fantasy of imminent death and panic.
\end{abstract}

Keywords: New coronavirus; Covid-19; Methods of treatment; Psychopathological effects.

\begin{abstract}
Versões contraditórias no campo da ciência: politização e desinformação na prevenção à Covid19: Para $80 \%$ dos infectados a Covid-19, nome da infecção que o novo coronavírus provoca, não passa de uma virose assintomática, com sintomas leves ou moderados. Porém, $5 \%$ dos indivíduos infectados desenvolvem sintomas muito graves, cujo tratamento é bastante complexo e pode levá-los a óbito. Difundiuse na grande imprensa a ideia de que no tratamento desta doença, o conhecimento médico-científico consolidado, ao longo da experiência no tratamento de infecções respiratórias similares não serviria para nada. Desta forma, produziu-se entre os médicos assistentes uma enorme timidez ao explicar à imprensa que a utilização de métodos tradicionais de tratamento ainda era válida e não precisaria de complicados experimentos científicos para justificá-los. No público atingido pelas campanhas movidas pela imprensa observamos efeitos psicopatológicos de angústia intensa, insônia, falta de ar, fantasia de morte iminente e pânico.
\end{abstract}

Palavras-chave: Covid-19; Novo coronavírus; Métodos tradicionais de tratamento; Efeitos psicopatológicos.

Versions contradictoires dans le domaine de la science : politisation et désinformation dans la prévention de Covid-19 : Pour $80 \%$ des personnes infectées par Covid-19, le nom de l'infection que provoque le nouveau coronavirus, il ne s'agit que d'une infection virale asymptomatique avec des symptômes légers ou modérés. Cependant, $5 \%$ des personnes infectées développent des symptômes très graves, dont le 
Revista aSEPHallus de Orientação Lacaniana

Núcleo Sephora de Pesquisa sobre o Moderno e o Contemporâneo

ISSN $1809-709 \mathrm{X}$

traitement est assez complexe et peut les conduire à la mort. Il semble que dans le traitement de cette maladie, les connaissances médico-scientifiques consolidées, grâce à l'expérience acquise dans le traitement d'infections respiratoires similaires, ne sont d'aucune utilité. Ainsi, une énorme timidité s'est manifestée parmi les médecins traitants lorsqu'ils ont eté appelés a expliquer à la presse que l'utilisation des méthodes traditionnelles de traitement était toujours valable et qu'il n'était pas nécessaire de recourir à des expériences scientifiques compliquées pour les justifier. Dans le public touché par les campagnes menées par la presse, nous avons observé des effets psychopathologiques d'angoisse intense, d'insomnie, d'essoufflement, de fantasme de mort imminente et de panique.

Mots-clés: Covid-19; Nouveau coronavirus; Méthodes traditionnelles de traitement; Effets psychopathologiques. 
Revista aSEPHallus de Orientação Lacaniana

Núcleo Sephora de Pesquisa sobre o Moderno e o Contemporâneo

ISSN 1809 - 709 X

\section{Contradictory versions in the field of science: politicisation and misinformation in the prevention of Covid-19}

Tania Coelho dos Santos

\section{Memories of the new coronavirus pandemic}

I was on my way to Paris on Thursday, February 19, 2020. The following week, the city of Rio de Janeiro would be taken by the usual horde of tourists. Carefree, they would invade the beaches baking under the hot sun. It wouldn't take long for them to lose themselves in the samba in some of our cheerful carnival blocks. Excited, they would soon discover that there is no sin below the equator. Nothing seemed more distant from the concern of the health authorities than the possible arrival of the new coronavirus. In other parts of the world though, this virus was already beginning to concern the most prudent people.

I did not think of buying masks to wear at the airport or on the plane, but I kept my physical distance, a handkerchief over my mouth and nose, and redoubled the concerns with hygiene, by avoiding taking my hands to my eyes, nose and mouth. I wore gloves for ten days. Yes, I was a little nervous. When I arrived I exchanged some thoughts with Patrice, my french taxi driver born in Taiwan. Used to pick me up and take me to the airport, he never misses the opportunity to tell me proudly about his family and his work in Paris. That day he was exultant with his new navy blue Mercedes all lined in white. I tried to find out if he was concerned about the possible arrival of the virus in France. He was oblivious to the problem and remained as cheerful and optimistic as usual. During my stay, I took extra care. I aired the room after the maid cleaned it and did not go out without protecting my nose and mouth. I started going to restaurants only when they were empty, keeping physical distance in the subway and also during my only visit to the Louvre.

It was no surprise when I read in Le Monde about the first recorded case, as the arrival of the virus in Europe was imminent. On February $24^{\text {th }}$ it was announced that there were no active cases in the country. On February $25^{\text {th }}$, Dominique Varoteaux, professor of technology at the Jeande-la-Fontaine University in Crépy-en-Valois and municipal councillor in Vaumoise, died of a pulmonary embolism at the Salpêtrière hospital in Paris. This 60-year-old man, infected with the virus, becomes the first French citizen to die from Covid-19 since the beginning of the global epidemic. Five new people were diagnosed with the disease on February $25^{\text {th }}$ and $26^{\text {th }}$.

Back in Brazil on February $29^{\text {th }}$, I had contracted a strong flu with a lot of cough, bronchitis and fever. I looked for my doctor to do a test, but no laboratory could offer it. Based on my jungle medicine and extensive experience in bronchitis episodes, I was convinced that it was not the corona. I only got serological confirmation of IGG and IGA negative on May $8^{\text {th }}$. I was lucky. Many people were not as lucky and once infected with the new coronavirus, they waited too long to receive the necessary care. Many of the deaths that occurred on the private health system in Rio 
Revista aSEPHallus de Orientação Lacaniana

Núcleo Sephora de Pesquisa sobre o Moderno e o Contemporâneo ISSN $1809-709 \mathrm{X}$

de Janeiro happened as a result of the delay in identifying the disease and providing early treatment.

Although I only stopped receiving my patients on March $23^{\text {rd }}$, I had already incorporated all the obsessive measures to prevent contagion, which would become the first psychopathological effects of the pandemic. Gestures as simple as touching the face, eyes, nose or mouth became dangerous threats, triggering permanent surveillance. Also a general anxiety, a mistrust of everything and everyone, compulsory sanitization of hands and groceries and pharmacy products, became a new obsessive compulsive symptom like strong schizo-paranoid tones. Very unsingular, these symptoms were shared with many other individuals psychologically infected by the insane fear of becoming contaminated.

\section{From normal ignorance to active misinformation}

The new coronavirus doesn't cause a common cold. For $80 \%$ of those infected with Covid19 , the name of the infection it causes, it is nothing more than a virus with mild symptoms or just a little uncomfortable. The phenomenon that nobody has been able to explain satisfactorily is: why $5 \%$ of infected individuals develop very serious symptoms, whose treatment is quite complex and does not guarantee that it can save them from death. Because of this detail, everything that has spread in the large press about the behaviour of the disease seemed to be based on the assumption that the consolidated medical-scientific knowledge, acquired throughout the experience in the treatment of similar respiratory infections - the Severe Acute Respiratory Syndromes (SARGS) - would be of no use in the case of this new infection. Thus, an enormous inhibition was produced among the attending physicians when explaining to the press that the use of traditional methods of treatment was still valid and would not need complicated scientific experiments to be justified. I bring a short excerpt from the article by a wise journalist, Euripides Alcantara, who was able to translate the issue that intimidated them very well:

Doctors at private hospitals in Brazil and the United States have prescribed hydroxychloroquine for young people with early symptoms of Covid-19, without heart problems or other comorbidities. I understand that they officially refuse to talk about this in order to escape the crossfire of the ideological debate about the drug. But it is a verifiable fact. Conclusion: in case I get infected with the new coronavirus I want the decision to take hydroxychloroquine to be made by the doctor in charge of my case. (Alcantara, 2020, May.)

What I am about to report seems like a joke, but it serves to shift the debate about the scientific value of hydroxychloroquine to a more politically neutral substance. About three months after the pandemic hit Brazil, scientists in England discovered that the use of the good old dexamethasone (commonly known in Brazil as Decadron) was very effective in combating a symptom, pneumonia. It was evident, in this case and in many others, that there was an overvaluation of scientific studies based on methodologies such as the double blind test, to test 
Revista aSEPHallus de Orientação Lacaniana

Núcleo Sephora de Pesquisa sobre o Moderno e o Contemporâneo

ISSN $1809-709 \mathrm{X}$

drugs whose clinical effectiveness had long been consolidated only on the basis of practical experience. A huge wave of mistrust erupted in the public debate spread in the press against certain traditional medical practices consolidated by recurrent successful use.

Thus, the biggest problem that this disease called Covid-19 brought us was the disorientation in the exercise of medical practice in both public and private health. The most common psychopathological effects on public opinion of this disorientation, was the spread of panic. Some individuals reacted to the conflict of versions with a defensive indifference to the heralds of danger. The poor quality of the scientific information conveyed by the press can be explained by the fact that among the scientific colleagues and the medical assistants, there was a lack of minimum consensus. Some researchers whom I consider highly competent and qualified were unable to convey their knowledge of the disease in a clear and orderly manner, helping the population to make well-oriented decisions. There was a great rush to convince public opinion of the virtues of isolation and for this the opinion formers made no effort to paint a dantesque picture of the infection.

The idea that the immune system of individuals over 60 , as well as those with some type of comorbidity (such as previous respiratory diseases, hypertension, obesity, diabetes and cardiovascular diseases in general) would be unable to defend itself in case of infection was widely disseminated. Having Covid-19 for a person over the age of 60 was almost a death sentence. All the elderly became highly vulnerable and responded with unbearable distress in the face of the imminent death threat. They locked themselves in their homes or, paradoxically, denied the dangers of the disease by recklessly throwing themselves on the streets. In analytical treatment, many of them testified to the state of panic in which they began to live through nightmares, psychosomatic illnesses and other symptoms of distress. Many people began to suffer from respiratory insufficiency of psychic origin, insomnia, uncontrollable crying episodes and nightmares in the face of the absolute certainty that death was very close. Time showed that the news coming from outside the country about the extreme vulnerability of the elderly was inaccurate. In fact, a huge number of them had only mild symptoms, became asymptomatic or were even hospitalized, but they recovered. The arguments in favour of believing in the fragility of the immune system of the elderly were based on a paradox, according to the information I found. Supposedly, because they had been exposed to a large amount of other viruses, they would have no defenses against this new virus. Children, according to this same paradox, would be immune to the new disease because they had low exposure to other viruses.

It was also not true that those with comorbidities would necessarily be more vulnerable to the virus. This only proved to be valid reasoning when the individual developed the severe form of the disease. In fact, people who developed the severe form of the disease, when they had comorbidities, were much more difficult to treat and to save from death. However, no one was able to provide a good explanation for the fact that some individuals, even when they were young 
Revista aSEPHallus de Orientação Lacaniana

Núcleo Sephora de Pesquisa sobre o Moderno e o Contemporâneo

ISSN $1809-709 \mathrm{X}$

and healthy, developed severe symptoms. Thus, all supposedly vulnerable individuals were exposed to massive propaganda of inaccurate and exaggerated information, which generated a threatening climate of irresponsible proportions. There is no question that the freedom of the press to inform is a non-negotiable value in a democratic society. However, many journalists understand that their mission is to train and not just inform public opinion. We suspect that many individuals have felt harassed by the fact that it seemed to them to be an exaggerated defense of a social isolation policy. In order to persuade public opinion, it seemed justifiable to draw a picture of the disease that was more threatening and deadly than reality.

This phenomenon demonstrates that the problem of fake news is very complex. The propaganda of inaccurate information can be triggered without necessarily the agent of the (un)informing campaign having the intention to lie, cheat or deceive. The beliefs of journalists aligned with a certain political orientation is enough to leave no room for contradiction, reducing the right of the population to information with a minimum of objectivity. In order to highlight this perception of the subject that I'm bringing, I would like to point out that at the moment in which I'm finishing this article, Brazil has reached the mark of almost 100,000 deaths. This is an immense number, we can only be saddened by it and sympathize with the families that have lost loved ones. The press, however, boasted that Brazil is the second country in the world in number of deaths, something highly vexing. Nevertheless, this information is incomplete, if it does not consider that in proportion to the relative size of the population, the number of deaths in Brazil is the same as in France and smaller than in Italy or England. There are many ways to manipulate public opinion without lying. One of them is to disclose absolute numbers and hide analyses based on statistical proportions. What is the interest that some journalists show in denigrating Brazil's reputation? To attack the current president and his political choices for the economy? Is it fair that this objective leads to belittling Brazil by conveying partial and distorted information?

The seriousness of the psychological effects of the epidemic, in my view, was due less to its unprecedented nature and much more to the lack of adequate transmission of the knowledge acquired through the experience of successful treatments in China and Europe. Why did so many doctors not know or resist the idea that early treatment with antivirals (such as azithromycin, hydroxychloroquine, ivermectin and other well-known drugs) could inhibit the proliferation of the virus in the early stages of the disease? Due to such discredit in early treatments, individuals were advised to stay at home, not to look for hospitals, to ask only for advice from their doctor over the phone, or to be guided by applications from the ministry of health. This is how many people developed a severe respiratory failure and were caught in the perverse trap of a disease that infects the nervous center, causing the patient to experience shortness of breath. Insensitive to the seriousness of his condition, the patient does not seek the hospital. The delay in receiving the appropriate treatment led many individuals, at the beginning of the pandemic, to develop the most 
Revista aSEPHallus de Orientação Lacaniana

Núcleo Sephora de Pesquisa sobre o Moderno e o Contemporâneo

ISSN $1809-709 \mathrm{X}$

serious form of the disease without being able to count on intensive treatment in time to halt the progress of the infection.

As a result of the lack of more reliable information, a form of war in the field of science developed itself in Brazil. Medical assistants advocating for the aforementioned early treatment and the appropriate use of traditional medications were opposed to radical epidemiologists convinced that prevention was better than treatment. Their disbelief in effective treatments even led them to a political campaign in defense of social isolation that fell to the taste of the press. The message to the general public was clear. There is no reliable treatment. Contagion must be avoided at all costs. Social isolation, however, was not feasible in poorer communities where population density is very high and people live in very small quarters. The Ministry of Health, at the beginning of the pandemic, embraced the cause of isolation and hand hygiene with great enthusiasm and did not remember to advocate alternative measures such as the use of homemade masks. The head of the ministry at the time, in a vigorous effort to publicize the measures that where being taken and to demonstrate the daily and careful monitoring of the advance of the epidemic, gathered a large number of journalists for a press conference every day. This showcase earned him the suspicion of being in a political campaign for governor of the state of Mato Grosso do Sul that ended up becoming a powerful fuel for his resignation. Unfortunately, the President's energetically negative attitude towards the gravity of the disease led to a politicization of the issue of prevention. Journalist Demetrio Magnoli portrays this situation well:

Political polarization has contaminated the discussions on the health crisis. The stock market's denial provoked a dogmatic reaction that dominates the press and the most enlightened part of public opinion: If Bolsonaro speaks of opening, we demand closing", Instead of the rational debate of costs and benefits of each specific health restriction, the voices outraged at the criminal negligence of the federal government take refuge in the generic clamor for lockdowns. In this step, supposedly progressive thinking is limited to reproducing the stock market primer - only turning it inside out". (Magnoli, 2020)

To add a little more folly to the debate, both Brazilian and American Presidents became ardent advocates of the early use of hydroxychloroquine. I believe it was a strategy to encourage people not to isolate themselves at home and stop going out to work. The defense of early treatment was interpreted by much of the press (Pasternak, N. et alli, 2020) as the defense of the preventive use of the drug. After that the discussion about this drug was completely politicized. On the right, the "brave" advocates of early treatment with hydroxychloroquine (or similar drugs like Ivermectin and Nitazoxanide) and anti-viral drugs like Azithromycin. On the left, the "conscious" advocates of extreme caution that only a rigid and prolonged social isolation could ensure. Science had reached the disappointing stage of being suspected of coloring political controversies, 
contributing to increasing misinformation and mood swings in the press. The behaviour of a large number of journalists, for this reason, was not commendable. They lacked impartiality and showed that they cannot stand the debate. The spirit of television soap operas dominated a debate between bandits and good people. Gay Talese, a well-known American journalist and writer, observed that the contemporary media behaves like the social networks. And in social networks, there is an abundance of lazy minds. He denounces the malicious maneuvers of journalists who introduce "pranks" into questions to induce the interviewee to make statements that would be detrimental to his integrity and reputation. And he goes even further by stating that: "Everyone has views on morality and justice. This does not mean that a one-sided view should be imposed on those who think differently and are contributing in a space of opinion". (Talese, 2020, August)

At the center of this disinformation dwelt the profound ignorance of the three phases that the disease goes through. On April $17^{\text {th }}$ I had access to a Zoom meeting organized by Sergio Margulies (posted on YouTube) between the hematologist and oncologist Daniel Tabak and the infectiologyst and researcher of UFRJ Mauro Schechter. I learned that the onset of the disease is just a common virus, but that if it evolves, severe respiratory failure occurs as a result of a complex inflammatory process in the lungs. That insufficiency is often not perceived as such. The infection reaches more peripheral neurological centers responsible for identifying shortness of breath. Thus the subject may neglect the severity of his condition. In addition, the disease can be thrombophilic and cause a dangerous cardiovascular picture. And finally, it can lead to severe immune unbalance, a storm of cytokines that require paradoxical immunodepression comes into play. Instead of this precious and realistic knowledge, we have seen in the press the adventures of the Ministry of Health in the desperate struggle to buy mechanical ventilators. Technical resources that have been overestimated as if all possible treatment had been reduced to that.

The Minister of Health also had difficulty in dealing with the differences between the public and private health systems. In an effort to avoid overcrowding public hospital emergencies, he widely recommended that all sick people stay at home. Early diagnosis and intervention were generally discouraged. In Rio de Janeiro, the epidemic first reached private hospitals in the South Zone and Barra da Tijuca. Encouraging patients with health plans not to go to private hospitals was not the best course of action. The epidemic took a little longer to reach the public network, which helped a lot to avoid its overloading before it was better equipped to receive the sick. Still, it was not the widespread recommendation not to look for public hospitals, however, which saved some of them from the much heralded chaos. It was an unusual fact that we observed in communities near the wealthiest regions of the city. We will return to that point below.

\section{From melancholic unpreparedness to the efficient response by private hospitals}

On March $21^{\text {st }} \mathrm{I}$ met in person for the last time the team of psychologists of the D'Or Network and the United Health Group (Rede Amil) that I supervise weekly. We began meeting 
Revista aSEPHallus de Orientação Lacaniana

Núcleo Sephora de Pesquisa sobre o Moderno e o Contemporâneo

ISSN 1809 - $709 \mathrm{X}$

virtually afterwards. On that occasion, I recommended that they look for hospital administrations to suggest the purchase of homemade masks. There was not enough personal protective equipment and it was reserved for healthcare professionals who were in direct contact with infected patients. I also suggested that we organize ourselves to work virtually and began to expand the employee assistance program to receive all those who presented anxiety symptoms related to the fear of contamination by the new coronavirus.

These private health networks surprised us very positively. At the beginning of March, all those who worked in hospitals were waiting for the apocalypse. There were not enough personal protective equipment or ICU beds, there was no protocol for the treatment of this as yet unknown disease, there were not enough trained intensivists or doctors to intubate the patients, much less mechanical ventilators. In a short time, at an impressive speed, new ICUs were opened, specialized equipment purchased, physicians hired, teams trained to assist and prevent contagion. And the critically ill patients arrived at the hospitals. It was expected that health professionals would be infected quickly or develop disabling psychological conditions and all this would lead to chaos.

None of this happened. The response of the largest private hospital networks in Rio de Janeiro proved equal to the challenge. The number of patients admitted and in need of ICU was enormous, but the announced overcrowding was never reached. The macabre fantasy that haunted hearts and minds was that health professionals would be forced to choose between who would receive a respirator and who would be handed over to their own luck. The lethality was relatively low and affected mostly patients who were being treated for other diseases, cancer in particular, or the elderly with some more serious comorbidities. The most surprising aspect was the large number of individuals who, regardless of how young they were, developed the severe form of the disease because of obesity. And there are still people who do not believe that obesity is a disease. People who think it's the politically incorrect prejudice or fatphobia. Another remarkable aspect was the number of male patients who developed the severe form of the disease. It is possible that this confirms an old observation that men take much less care of their health than women. Or, perhaps, hormonal differences explain the phenomenon.

As the supervisor of the teams of psychologists working in the assistance of some of the largest private hospitals in the South Zone of Rio and Barra da Tijuca, I was witness to the tireless effort and unconditional support of the hospital administrations to our work. In a short time the virtual care of patients with Covid-19 and their families expanded and proved to be very responsible and efficient. What caught my attention the most, however, was the work with the collaborators. If at the beginning of the pandemic many of them seemed fragile and very afraid of contaminating themselves or their families, the fast and abundant distribution of personal protective equipment changed this picture. Instead of the anxiety crisis, panic and the exodus of professionals, we could witness the high commitment they showed in facing the multiple challenges. 
Revista aSEPHallus de Orientação Lacaniana

Núcleo Sephora de Pesquisa sobre o Moderno e o Contemporâneo

ISSN $1809-709 \mathrm{X}$

Through interviews with ICU and emergency medical coordinators, as well as with the head of nursing (Coelho dos Santos et alli, 2020) we were able to collect the memories of the immense effort to adapt to a routine that involved from prevention to contagion to the exhaustive dedication to numerous patients who required very specialized and highly individualized care. It is remarkable to observe the replacement of a melancholy environment of apprehension and unpreparedness among medical professionals, nurses and nursing technicians by a spirit of confrontation and high self-denial. In all the interviews with professionals who were in the front line we could verify the importance of the leadership exercised by the management of the private network hospitals.

I did not directly follow the efforts of the public network in treating patients. I only had news through some isolated experiences that were brought to me by my analysts who are doctors and work in public hospitals. In particular, what was reported to me by an analyst about Gávea's campaign hospital caught my attention. The patients referred there came from far away and, contrary to what was expected, did not come from the hyperpopulated communities ("favelas") of the South Zone of the city, São Conrado and Barra da Tijuca. In addition, I emphasize the courage, dedication and commitment that these doctors demonstrated. In particular, I highlight the extreme deprivation of essential comforts that they had to face such as: feeding when you are hungry or urinating when you are in need. Prepping and de-prepping are arduous tasks and the equipment is rationed. Being on duty in ICUs with patients from Covid-19, in the so-called covidarians, requires that the on duty physician suspend these essential needs for six consecutive hours. This is especially painful for women, besides being conducive to the development of urinary tract infections, as an analyst who worked at Gaffrée and Guinle told me.

\section{When the disease gets to the communities it will be chaos!}

This phrase circulated by word of mouth in Rio de Janeiro and translated the certainty that the apocalypse was coming. We knew that the strategy to fight the epidemic based on social isolation was inadequate for the communities of Rio de Janeiro. However, a rather unusual fact that deserves further study was the following: the end of the world has not arrived. The disease that brought a large number of people from the most affluent social groups to hospitals did not bring a catastrophe to the communities of Rio de Janeiro. The number of individuals who had to be hospitalized in a serious condition in Rocinha, Vidigal, Rio das Pedras, Tijuquinha, Muzema, Maré, was not calamitous. On the contrary, it is surprising that, not being able to follow the guidance of the Ministry of Health to remain in isolation, the lethality in these groups was not more expressive.

An unprecedented research by the Institute of Applied Economic Research (Ipea) does not seem to corroborate our intuitive perception of the phenomenon, since it showed that $79.6 \%$ of the 6735 deaths registered in the capital of the state until June $13^{\text {th }}$ occurred in the poorest areas of the city, far from the South Zone, Barra, Greater Tijuca where the social development index is 
Revista aSEPHallus de Orientação Lacaniana

Núcleo Sephora de Pesquisa sobre o Moderno e o Contemporâneo

ISSN $1809-709 \mathrm{X}$

highest. If we analyze the data more carefully, however, we may be on the right track. Rocinha, for example, was included in Zone 1, the lowest SDI, along with the Complexo do Alemão, Camorim, Deodoro, Acari, Parada de Lucas and Jacarepaguá. It was observed that the lethality rate in all age groups was much higher than in zone 5 which includes the South Zone, Barra, Tijuca, Meier and Jardim Guanabara. The intuitive perception that there was no chaos in the favelas near the South Zone and Barra cannot, however, be correctly gauged, as data about these regions is diluted among information regarding the other poorer regions of the capital. If Rocinha and Vidigal are part of zone 1 (the poorest in the city and the smallest SDI) why didn't Gávea's Campaign Hospital, inaugurated on April 23rd, receive a huge number of patients from this region? Where would they have been sent? Why did the residents of this region not report a significant incidence of deaths? Only one explanation occurs to me for such a distance between the reality that I observed in my surrounding and the IPEA data: the lethality distribution in zone 1 (the poorest) was not uniform. Regions with identical SDI may not have had the same lethality rate. This was not a research question. It is not politically correct. Unfortunately, science does not always take contingency into account. Perhaps the communities closest to the wealthiest regions of the city have not suffered the same impact as others, equally poor, but situated in other localities. Perhaps the support of the residents around these communities has done much to significantly reduce the impact of the epidemic.

\section{The secret of the unequal immune response to the virus}

The debate on vulnerability to the new coronavirus has brought to light some immunological puzzles that are far from being deciphered. Some researchers debate the importance of cross-immunity. Tuberculosis vaccination, the old BCG, would be one of the possible answers to the question that will not be silenced: why do so many people not get the disease? There is no definitive evidence that the Bacille Calmette-Guérin (BCG) vaccine protects people against infection by the new virus. Two clinical trials addressing this issue are underway, and the WHO (world health organization) will evaluate the definitive evidence when available. However, there is experimental evidence from animal and human studies that the BCG vaccine has broader non-specific effects on the immune system whose relevance has not yet been well characterized. However, the review of this research has produced two protocols registered for clinical trials aimed at studying the effects of BCG vaccination on health professionals directly involved in the care of patients with Covid-19. On April 11, 2020, the WHO updated its ongoing review of evidence from major scientific databases and clinical trial repositories, using research terms in English, French and Chinese for Covid-19, coronavirus, SARS-CoV-2 and BCG. The review produced three preprints (manuscripts published online before peer review) in which the authors compared the incidence of Covid-19 cases in countries where BCG vaccine is used to countries where it is not and noted that countries that routinely used the vaccine in neonates had fewer reported cases of Covid-19 until 
Revista aSEPHallus de Orientação Lacaniana

Núcleo Sephora de Pesquisa sobre o Moderno e o Contemporâneo

ISSN $1809-709 \mathrm{X}$

that time. Although such studies are prone to a significant bias in many confounding factors, including differences in national demographics and disease burden, test rates for virus infections, and the stage of the pandemic in each country, there is preliminary evidence in favor of the effects of BCG.

Other researchers (Pereira, R.C., Health/April, 2020) have suggested that the secret of immunity lies in high rates of vitamin $D$, a very potent hormone. In order to produce it, under the exposure to sunlight, the body transforms its available ergosterol production into it. Ergosterol is a sterol that is a precursor of Vitamin D2. (Wikipedia) It is transformed into viosterol by the action of ultraviolet light and is then converted into ergocalciferol, which is a form of vitamin D. The prevention of the disease in a solar country like Brazil could have counted on a broad campaign to reinforce vitamin $\mathrm{D}$. We know that many attending physicians have advised their private patients to strengthen immunity by taking vitamin supplements. Vitamin $D$ is very important to the human body. In addition to its best known functions related to bone health, it is also responsible for other activities, working as a growth regulator, immune system, cardiovascular, muscles, metabolism and insulin. But when discovered, it was believed that it could only be acquired through food. It was in the 1970s that scientists discovered that the vitamin was a hormone and not a vitamin, but its nomenclature was already consolidated and remained so. It can still be found in a few foods, such as greasy fish, cod liver oil and dried mushrooms. Milk, eggs and beef liver also have the vitamin, but in smaller amounts. These foods are not typical of the diet of the low-income population. In addition, to meet the daily need for vitamin $\mathrm{D}$, large quantities of these foods are required. On the other hand, the main source in our bodies comes from its synthesis in the skin, by the action of sunlight. Vitamin D is liposoluble, that is, to be absorbed in the intestine, it needs the presence of fats, when acquired through food. The main source of vitamin $D$ is our skin, the ideal is to sunbathe without sunscreen for at least 20 minutes a day. The cells that are part of the immune system, such as lymphocytes, have receptors for vitamin D, which acts to strengthen the defense system, helping to prevent diseases. Considering that the low-income population does not usually feed well, would massive exposure to sunlight justify the high degree of immunity that could explain the low mortality in the communities mentioned above?

No less important is intracellular immunity. It's not just the antibodies that protect us from the virus. T-lymphocytes or T-cells are immune system cells and also a group of white blood cells (leukocytes) responsible for the body's defense against unknown agents (Wikipedia). Its main role is as specific immunity, cellular immunity, inducing apoptosis (self-destruction) of damaged cells, invaded by viruses, intracellular bacteria, or cancerous. They differ according to their function in: cytotoxic (CD8), auxiliary (CD4), natural killer (NKT), memory (CD45), regulatory (FOXP3) or gamma-delta $(\gamma \delta)$. They mature in the thymus, so they are called lymphocytes.

Finally, there is an entire discussion about genetic immunity. Why do a few people develop severe forms of Covid-19, while many others remain asymptomatic? Researcher Mayana Zatz 
Revista aSEPHallus de Orientação Lacaniana

Núcleo Sephora de Pesquisa sobre o Moderno e o Contemporâneo ISSN $1809-709 \mathrm{X}$

(Mariz, F. Jornal da USP, 2020), director of the Federal University of São Paulo (USP) Human Genome and Stem Cell Research Center (CEGH-CEL), is participating in an international research group that seeks to understand how genes influence the disease. One of the characteristics of new coronavirus infection is the variability of symptoms in infected people. She has found that most people develop mild symptoms or remain asymptomatic, but about $1 \%$ of people with symptoms can have severe and lethal forms. This difference in response to the new coronavirus infection depends on our genome. For this reason, the geneticist clarifies that the scientists involved in the study, in partnership with Professor Paulo Saldiva, from the School of Medicine (FM) at USP, wants to identify the genetic variants of risk and the protective variants. It was observed that there are super elderly individuals (people aged over 85 years old) who have been exposed to the virus but have not developed symptoms or have managed to cure themselves of the infection. On the other hand we see young individuals, especially males, who have developed the severe form of the disease. And it is very likely that the main reason for vulnerability to the virus depends essentially on the genome of each individual. Knowing which genomes are at risk and which ones involve protective genes is by far the most effective measure to establish a strategy for preventing the disease and also for vaccination.

A large European research consortium (Heise, 2020) has already analysed the genome of thousands of patients and suggested that part of the resistance can be explained by the genes in $A B O$ blood groups. People with type $A$ blood would be more vulnerable and those with type $O$ would be more resistant. The others, ( $B$ and $A B$ ) would be in between. Many things are still unclear and may explain why the apocalypse did not come.

\section{Misinformation, politicization and psychopathology: is there a vaccine against it?}

I have obtained much of this information from Internet research conducted solely out of my holy curiosity. In the big press a small part of this information arrived late, quite insufficiently and badly presented. Instead of objective, well-founded, clear and widely explained information, I found a huge amount of demonstrations and advice from epidemiologists convinced that they understand everything. Nothing is further from the scientific spirit than absolute certainty. Nothing is closer to the desire to suggest, influence and dominate lazy minds than these psychological states of high conviction. Nothing is more likely to spread the worst of all psychopathological effects, paranoia, than the taste of so many scientists for certainty. They actively contribute to the exaggerated political polarization that dominates all debates today. They exacerbate the dominant hysterical symptom that consists in rejecting what is complex and believing that there is a simple solution for everything. They increase the childish tendency, reigning in our time, of seeking an evil Other to blame for what we cannot control, avoid or prevent. It could be my neighbor who doesn't wear a mask. It could be the old man who rejects social isolation. Or the young man who crowds with other 
young people in the bar.

Soon all those who refuse to take the vaccine will be canceled. This is what Science's editor in chief, Holden Thorp (Eller, 2020), announces in advance because he believes there is a correlation between the defense of hydroxychloroquine and the anti-vaccine movement. This approach to the position of individuals who have committed the anti-scientific crime of believing in early treatment with anti-virals serves to demonstrate the degree of anti-democratic polarization. After all, the anti-vaccine movement grows among progressive, politically correct and left-wing individuals. It has nothing to do with the brazilian or the American president's coreligionists. Our idea of democracy, in times of one-sided progressive and politically correct speeches, has become the enemy of individual freedom. The patrolling of freedom of opinion violates freedom of expression. We are living in a dangerous world. The fear of having your reputation slandered has led many people to silence themselves. The result of this culture of cancellation is the electoral surprises that silenced majorities can prepare for progressive, globalized intelligence, convinced that their opinion is the only possible opinion, the only one that is politically correct, morally just and religiously sanctioned.

\section{References}

Alcântara, E. (2020, mai.). O médico decide O Globo. Medscape. Recuperado de https://oglobo.globo.com/opiniao/o-medico-decide-24441685

Altino, L. (2020, ago.). Menos dinheiro e mais dor Rio. $O$ Globo. Recuperado de https://oglobo.globo.com/rio/conheca-os-bairros-do-rio-com-as-maiores-taxas-demortalidade-por-casos-da-covid-19-24562333

Duqueroy, v. (2020, abr.). França publica mais dados sobre hidroxicloroquina e surgem mais dúvidas, Medscape. Recuperado de https://portugues.medscape.com/verartigo/6504711.

Eller, J. (2020, ago.) Entrevista com Holden Thorp. $O$ Globo Recuperado de https://oglobo.globo.com/sociedade/coronavirus/temo-que-as-pessoas-deixem-de-sevacinar-diz-editor-chefe-da-revista-science-1-24562178

Frellick, M. (2020, jun.) Hidroxicloroquina não previne a Covid-19 em um estudo randomizado. Medscape. Recuperado de https://portugues.medscape.com/verartigo/6504912.

Frellick, M. (2020, abr.) Mais um estudo confuso sobre hidroxicloroquina. Medscape. Recuperado de https://portugues.medscape.com/verartigo/6504753.

Grünewald, S. T. (2020, jul.) Pesquisa brasileira destaca ausência de benefício com hidroxicloroquina na covid-19. Medscape. Recuperado de https://portugues.medscape.com/verartigo/6505122. 


$$
\begin{aligned}
& \text { Revista aSEPHallus de Orientação Lacaniana } \\
& \text { Núcleo Sephora de Pesquisa sobre o Moderno e o Contemporâneo } \\
& \text { ISSN } 1809 \text { - } 709 \text { X }
\end{aligned}
$$

Heise, G. (2020, jun.). Tipo sanguíneo pode influenciar evolução da covid-19. Recuperado de https://www.dw.com/pt-br/tipo-sangu\%C3\%ADneo-pode-influenciarevolu\%C3\%A7\%C3\%A3o-da-covid-19-diz-estudo/a-53874013

Kirkner, R.M. (2020, jun.). Covid-19: Distanciamento físico funciona e máscara N95 é a melhor, diz análise. Medscape. Recuperado de: https://portugues.medscape.com/verartigo/6504913

https://pt.wikipedia.org/wiki/Linf\%C3\%B3cito_T\#: :text=Linf\%C3\%B3citos\%20T\%20ou \%20c\%C3\%A9lulas\%20T, contra\%20agentes\%20desconhecidos\%20(ant\%C3\%ADgenos).

Magnoli, D. (2020, ago.). O único consenso nacional. $O$ Globo. Recuperado de: https://oglobo.globo.com/opiniao/o-unico-consenso-nacional-24575452

Tabak, D., Schechter, M. (2020, abr.). Recuperado de: https://www.youtube.com/watch?v=DiAASIbyHmQ

Zatz, M. (2020, jun.). Pesquisa quer identificar genes responsáveis por forma grave da covid-19. Medscape. Recuperado de https://jornal.usp.br/radio-usp/passaporte-da-imunidade-contracovid-19-ainda-gera-polemica-2/

McCall, B. (2020, mai.). Covid-19: Será a reposição de vitamina D uma solução simples e ao nosso alcance? Medscape. https://portugues.medscape.com/verartigo/6504877.

Medscape, E. (2020, jun.). Dexametasona reduz mortes em pacientes com covid-19 grave. Medscape. Recuperado de https://portugues.medscape.com/verartigo/6504944.

Miller, J.A. (2010.). L'Autre Mechant six cas cliniques commentés, Collection La Bibliothèque Lacanienne 4. Paris : Navarin.

Miranda, G. (2020, jun.). Isolamento horizontal x isolamento vertical: quais são as evidências? Medscape. Recuperado de https://portugues.medscape.com/verartigo/6504970.

Otto, M. A. (2020, mai.). Apresentações incomuns da Covid-19: 'Nossa ignorância é profunda'. Medscape. Recuperado de https://portugues.medscape.com/verartigo/6504822.

Pasternak, N., Schechter, M., Tabak, D. (2020, jul.). O holocausto e a cloroquina. Medscape. Recuperado de https://oglobo.globo.com/opiniao/o-holocausto-a-cloroquina-24532831.

Dias, B.C. (2020, mai.). Ineficácia da cloroquina contra a Covid-19 é confirmada em revisão de 70 referências. Recuperado de https://www.abrasco.org.br/site/noticias/especialcoronavirus/ineficacia-cloroquina-covid19-cientistas-anm/48463/

Pereira, R. C. (2020, mai.). Saúde Abril. A vitamina da controvérsia. Medscape. Recuperado de https://saude.abril.com.br/alimentacao/a-vitamina-da-controversia/

Salamon, M. (2020, jun.). Obesidade agrava Covid-19 em pacientes jovens? Medscape. Recuperado de: https://portugues.medscape.com/verartigo/6504903.

Tabakman, R. (2020, jun.). Higiene e limpeza na pandemia: A linha tênue entre precaução e obsessão. Medscape. Recuperado de https://portugues.medscape.com/verartigo/6504902. 
Revista aSEPHallus de Orientação Lacaniana

Núcleo Sephora de Pesquisa sobre o Moderno e o Contemporâneo

ISSN 1809 - $709 \mathrm{X}$

Talese, G. (2020, ago.). Sou absolutista da liberdade de expressão. O Globo. Recuperado de https://oglobo.globo.com/cultura/gay-talese-comenta-demissoes-no-new-york-times-

cultura-do-cancelamento-24562679

Tarantino, M. (2002, jun.). Maioria dos médicos aprova isolamento; APM vê perigo em flexibilizar agora, Recuperado de: https://portugues.medscape.com/verartigo/6504900

Vitamina D. Recuperado de https://pt.wikipedia.org/wiki/Vitamina_D

Citação/Citation: Coelho dos Santos, T. (nov. 2019 a abr. 2020). Contradictory versions in the field of Science: politicisation and misinformation in the prevention of Covid-19. Revista aSEPHallus de Orientação Lacaniana, 15(29), 23-38. Disponível em www.isepol.com/asephallus. Doi: 10.17852/1809709x.2020v15n29p23-38

Editor do artigo: Tania Coelho dos Santos.

Recebido/Received: 10/03/2019 / 03/10/2019.

Aceito/Accepted: 10/20/2019 / 20/10/2019.

Copyright: (c) 2019 Associação Núcleo Sephora de Pesquisa sobre o moderno e o contemporâneo. Este é um artigo de livre acesso, que permite uso irrestrito, distribuição e reprodução em qualquer meio, desde que $o$ autor e a fonte sejam citados/This is an open-access article, which permites unrestricted use, distribution, and reproduction in any medium, provided the author and source are credited. 